\title{
Comparative efficiency of oxygen therapy in patients (smokers and non-smokers) with chronic obstructive pulmanory disease
}

\author{
Nikolay I. Starodumov ${ }^{1}$, E.G. Zarubina ${ }^{2}$ and I.O. Prokhorenko ${ }^{2}$ \\ ${ }^{1}$ Samara Ministry of Public Health and Social Development \\ ${ }^{2}$ Samara Medical Institute "Reaviz"
}

Accepted 23 July 2012

Original Text in Russian (C) Starodumov NI, Zarubina EG, Prokhorenko IO, 2011, published in Saratov Journal of Medical Scientific Research 2011; 7(2): 420422.

Abstract: The decrease in clinical efficacy of oxygen therapy takes place in patients suffering from chronic pulmonary obstructive disease who continue smoking even if the intensity of smoking is getting lower. It is explained by the damage of oxygen utilization regardless of normalization of arterial blood saturation indices and perfusion oxygen saturation indices in blood flow.

Keywords: chronic obstructive pulmonary disease, smoking, oxygen therapy, microcirculation.

Cite as Starodumov NI, Zarubina EG, Prokhorenko IO. Comparative efficiency of oxygen therapy in patients (smokers and non-smokers) with chronic obstructive pulmanory disease. Russian Open Medical Journal 2012; 1: 0207.

Correspondence to Nikolay I. Starodumov. Address: 73, Leninskaya str., Samara, 443020, Russia. Phone: +79171609654. E-mail: ingaproch@rambler.ru

\section{Introduction}

Oxygen therapy can variously influence our organism, but the most important thing is that it compensates hypoxia in tissues, and also in patients with chronic pulmonary obstructive disease (COPD) [1-4]. In patients with respiratory failure during oxygen administration its tension in an alveolar air and blood plasma increases. This is the reason of oxyhemoglobin concentration increasing in arterial blood. Nevertheless many patients with COPD keep on smoking having lung pathology $[1,5,6]$. Nicotine is not just a drug leading to fast addiction, but it is also a potential pharmacological agent [7]. It stimulates thrombocytes and fibrinogens production which block blood vessels. This finally leads to peripheral blood flow disorders because of the intensive tissue oxygen consumption. [3]. As the researching displays, microcirculation reduces to $19 \%$ after two cigarettes $[3,7]$.

Our study aimed to research influence of smoking on the efficiency of oxygen therapy in patients with COPD.

\section{Material and Methods}

58 patients with severe COPD were examined. They have been smoking for 20 years 20 packs of cigarettes and more per month. All of them were men at the age of $45.8 \pm 3.6$ years; they all were comparable in co-morbidity spectral range. 31 of the patients have given up smoking after verification of COPD (group I) during the examination. The non-smoking period was 4 years mimimum. The other 27 patients kept on smoking (group II). They smoked an average of $13.2 \pm 2.1$ cigarettes per day.

Before admission to hospital the patients of the both groups had been examined in the period of the main disease recurrence before and on a background of the slow oxygen therapy ( $3 \mathrm{l} / \mathrm{min}$ ). To estimate the condition of microcirculation the method of laser Doppler flowmetry with spectral analysis of wavering (featurepacked diagnostic laser equipment "LAKK-M" (Lasma LLC, Russia) was used). The aim was to determine an average mean perfusion (M, perf. u.), capillary blood saturation $\left(\mathrm{SO}_{2}, \%\right)$, erythrocyte volume fraction $\left(\mathrm{Vr}, \mathrm{mm}^{3}\right)$, perfusion oxygen saturation index of microcirculation ( $\mathrm{SOm}=\mathrm{SO}_{2} / \mathrm{M}$, c.u.), tissue oxygen cost index $\left(\mathrm{U}=\mathrm{SpO}_{2} / \mathrm{SO}_{2}, \mathrm{c}\right.$. u. $)$, arterial blood saturation in right hand fingerpads $\left(\mathrm{SpO}_{2}\right)$.

\section{Results and Discussion}

The study displayed that the patients from the groups I and II had different reactions to the oxygen therapy despite the similarity of symptoms and recrudescence severity level. So, in patients of the group I peripheral microcirculation parameters increased $(p<0.05)$ and were constant during the therapy. The peripheral microcirculation dynamics in group II was different because of oxygen (Table).

As the table shows in patients from the group I there have been fixed a resurrection of arterial blood homeostasis in an hour after the therapy. Perfusion oxygen saturation index of microcirculation increased within 1 and 2 hour to $21.3 \%$ and $38.3 \%$ respectively $(p<0.05)$, which have led to an increase of tissue oxygen cost index within 2 hours $(19.1 \%$ on the average; $p<0.05)$. An improvement of tissue oxygen perfusion was confirmed by a heart rate fall from 98 up to $74 \mathrm{bpm}(2.4 \% ; \mathrm{p}<0.05)$ on the background of reducing blood perfusion volume.

In patients of the groups I and II perfusion oxygen saturation index of microcirculation increased with increase of the oxygen therapy length. Besides there was a development of capillary blood saturation, tissue oxygen cost index and perfusion volume $(\mathrm{M} n \mathrm{Vr}$ ) within 2 hours after the beginning of the treatment. This probably was caused by microvascular spasm and blood circulation. These changes in vasculature reaction to oxygen inhaling can be determined by changes in endothelium vasomotion under the influence of smoking and lipid peroxidation process peculiar to heavy smokers. 
Table. Peripheral microcirculation parameters in patients with COPD who gave up smoking (group I) and keeping on smoking (group II).

\begin{tabular}{|c|c|c|c|c|c|c|}
\hline \multirow{3}{*}{ Indicator } & \multirow{2}{*}{\multicolumn{2}{|c|}{ Before oxygen therapy }} & \multicolumn{4}{|c|}{ After starting oxygen therapy } \\
\hline & & & \multicolumn{2}{|c|}{ After 1 hour } & \multicolumn{2}{|c|}{ After 2 hours } \\
\hline & group I & group II & group I & group II & group I & group II \\
\hline M, perf. u. & $18.2 \pm 0.8$ & $21.6 \pm 0.9$ & $15.5 \pm 0.7$ & $18.4 \pm 0.7$ & $12.2 \pm 0.5$ & $10.2 \pm 0.6$ \\
\hline $\mathrm{SO}_{2}, \%$ & $85.6 \pm 1.3$ & $85.8 \pm 1.4$ & $84.6 \pm 1.4$ & $85.6 \pm 1.3$ & $79.2 \pm 1.5$ & $90.3 \pm 1.2$ \\
\hline $\mathrm{SpO}_{2}$ & $89.8 \pm 0.1$ & $89.6 \pm 0.2$ & $98.8 \pm 0.1$ & $98.1 \pm 0.2$ & $98.9 \pm 0.1$ & $98.2 \pm 0.1$ \\
\hline $\mathrm{Vr}, \mathrm{mm}^{3}$ & $18.3 \pm 0.5$ & $20.3 \pm 0.5$ & $16.6 \pm 0.3$ & $18.4 \pm 0.3$ & $12.1 \pm 0.2$ & $9.1 \pm 0.2$ \\
\hline $\mathrm{SOm}=\mathrm{SO} 2$ / M, c.u. & 4.7 & 4.0 & 5.7 & 4.6 & 6.5 & 8.8 \\
\hline $\mathrm{U}=\mathrm{SpO} 2 / \mathrm{SO} 2, \mathrm{c} . \mathrm{u}$. & 1.05 & 1.04 & 1.15 & 1.15 & 1.25 & 1.08 \\
\hline Heart rate, bpm & $98.6 \pm 2.2$ & $102.8 \pm 2.6$ & $86.4 \pm 2.4$ & $85.4 \pm 2.1$ & $74.1 \pm 3.2$ & $96.3 \pm 3.3$ \\
\hline
\end{tabular}

\section{Conclusion}

So, in patients keeping on smoking with COPD we have fixed reducing of the efficiency of oxygen therapy even if they smoked less. This is connected to oxygen extraction disorders even on the background of high arterial blood saturation and perfusion oxygen saturation of microcirculation.

\section{Reference}

1. Avdeyev SN, Tsaryova NA, Nekl'udova GV, Chuchalin AG. Ingalyatsionnyi oksid azota pri lyogochnoy gipertenzii u bol'nykh s obostreniyem KhOBL. [Inhalation nitrogen oxide in pulmonary hypertention in patients with recrudescence of COPD]. Serdechnaya nedostatochnost 2003; (4): 251-255.

2. Yemelyanov AV. Diagnostika i lecheniye obostrenyi khronicheskoi obstruktivnoi bolezni lyogkikh.. [Recrudescence of chronic obstructive pulmanory disease diagnostics and treatment]. Russkiy meditsinskiy zhurnal 2004; 13(4): 183-189.

3. Nesterov OI. Sostoyaniye mikrotsirkulyatornogo rusla u bolnykh khronicheskimi nespetsificheskimi zabolevaniyami lyogkikh [Microvasculature condition in patients with chronic nonspecific pulmonary diseases]. Moscow, Russia: author's abstract, 2008, 25 p.

4. Milionis HJ, Rizos E, Mikhailidis DP. Smoking diminishes the beneficial effect of statins: observations from the landmark trials. Angiology 2007; 52: 575-587 (doi: 10.1177/000331970105200901) (PMID: 11570656).

5. Davis JW, Shelton L, Eigenberg DA. Effects of tobacco and non-tobacco cigarette smoking on endothelium and platelets. Clin Pharmacol Ther 2005; 37(5): 529-533 (PMID: 3987176).

6. Pittilo RM. Cigarette smoking, endothelial injury and atherosclerosis. $J$ Smoking Related Dis 1993; 4: 17-25.

7. Wright JL, Levy RD, Churg A. Pulmonary hypertension in chronic obstructive pulmonary disease: current theories of pathogenesis and their implication for treatment. Thorax 2005; 60: 605-609 (PMID: 15994270) (doi:10.1136/thx.2005.042994).

\section{Authors (2011 year):}

Nikolay I. Starodumov - MD, Consultant Samara Ministry of Public Health and Social Development, Samara, Russia;

E.G. Zarubina - MD, D.Sc., Professor, Head of Department of Medical and Biological Disciplines, Samara Medical Institute «Reaviz», Samara, Russia;

I.O. Prokhorenko - MD, PhD, Associate Professor, Department of Internal Medicine, Samara Medical Institute «Reaviz», Samara, Russia. 